Article

\title{
Community-Managed Water Supply Systems in Rural Uganda: The Role of Participation and Capacity Development
}

\author{
Daniel Etongo ${ }^{1, *}$, G. Honor Fagan ${ }^{1}$, Consolata Kabonesa ${ }^{2}$ and Richard Asaba B. ${ }^{2,3}$ \\ 1 National Institute for Regional and Spatial Analysis (NIRSA), Maynooth University, \\ Maynooth W23 F2H6, Ireland; honor.fagan@mu.ie \\ 2 School of Women and Gender Studies, Makerere University, Kampala P.O. Box 7062, Uganda; \\ consolata.kabonesa@gmail.com (C.K.); rasabab@yahoo.com (R.A.B.) \\ 3 Department of Development, Peace and Conflict Studies, Kampala International University, \\ Kampala P.O. Box 20000, Uganda \\ * Correspondence: Daniel.Etongo@mu.ie; Tel.: +35-301-708-6178
}

Received: 8 August 2018; Accepted: 13 September 2018; Published: 18 September 2018

\begin{abstract}
Over 85\% of Uganda's 34 million people depend on rural water supply systems and the current water and environment sector performance report (2017) reports an $84 \%$ functionality of rural water sources such as boreholes and shallow wells with a hand pump. Ensuring the continued operation of water points, and in keeping with participatory theory, the water user's committees (WUCs) should also be a vehicle for empowering communities while bringing about greater equity of use. However, WUC members do not acquire the knowledge and skills they need by default but require different types of training. This study sought to evaluate community participation and capacity development in WUCs in relation to community-managed water supply systems. A shared dialogue workshop (SDW), as well as 642 randomly selected households across 17 villages in two Parishes in Lwengo district, southern Uganda were considered. Results indicated that $41.7 \%$ of surveyed households used an unprotected source while up to $30 \%$ had a member in a WUC. Fifty-two percent of households had never made any financial contributions to a WUC, while $34.6 \%$ did so on an ad hoc basis. This paper examines the relationship between participation, mobilization, and financial contributions. The chi-square test indicated mobilization has no impact on household financial contributions to a WUC. However, the majority of even those households that were mobilized made a payment only occasionally, and specifically when the source broke down. Additionally, the test result reveals that there is no difference between better off and relatively poor households in their contributions to a WUC, an indication that other factors influence such decisions. Training activities, especially on the operation and maintenance of water points and to undertake minor repairs, were mostly provided by non-governmental organizations (NGOs)/ project staff. Abandoned boreholes, lack of rehabilitation activities, and loss of enthusiasm are all indications that the technical, financial, and institutional performance of community-managed water supply systems needs improvement.
\end{abstract}

Keywords: water access; ownership; performance; climate change; sustainability; Uganda

\section{Introduction}

Community-based management (CBM) has proven to be an enduring strategy for operationalizing mainstream participatory development in rural water supply projects and programmes in sub-Saharan Africa [1,2]. This participatory agenda took hold in the 1980s, the first UN "Water Decade", in the face of general disillusionment with top-down and supply-driven approaches [3,4]. The drive towards public participation and decision-making at local levels was echoed more broadly in Agenda 21, a core 
output of the 1992 "Earth Summit" in Rio de Janeiro. As a result of these developments, the CBM model became a central tenet of major policy and practitioner discourses on rural water supply $[5,6]$ especially given the potential of this approach for improving participation and water governance in rural vulnerable communities in Africa.

The basic principles behind this concept according to Harvey and Reed [7] are that communities benefiting from an improved water supply should have a major role in its development, own the water system or facility, and have overall responsibility for its operation and maintenance (O\&M). In order for rural communities to achieve the intended objectives of the community management model, Water Point Committees (WPC) are created. The WPC is also known as a Water User Committee (WUC), Water Management Committee (WMC), or Water and Sanitation Committee (WSC). These are typically committees of 6 to 10 elected community members or otherwise delegated by their community to take responsibility for a water point. Examples of these waterpoints would be an Afridev hand pump, a conventional lever-action hand pump designed for heavy-duty use that is fully corrosion resistant, easy to install, and has excellent potential for community-based maintenance [8], deep and shallow wells, protected springs, public taps from gravity flow schemes, and rainwater harvesting [9]. Responsibilities of these committees are both technical (maintaining and repairing the water point) and financial (collecting and saving community contributions so that funds are available for maintenance and repairs), of which its effectiveness would ensure the sustainability of water points [10,11].

However, Baumann [12] estimated that 35\% of all rural water supply systems in sub-Saharan Africa are not functioning, while two studies in same sub-region further indicated operational failure rates of 30 and $60 \%$ in rural water supply projects $[13,14]$. Additionally, a study conducted in Tanzania suggested that one-quarter of new water points become non-functional within two years of installation [15]. An earlier study conducted in Makondo Parish in Uganda indicated that over 50\% of water pumps have remained idle and useless to communities due to the lack of maintenance [16]. This figure is similar to a recent study conducted in seven countries across sub Saharan Africa [17]. Therefore, the reasons cited for water point failure are multifaceted and include a multitude of natural, technical, social, cultural, and financial factors [18-20]. Specifically, water point failures are connected to the low recharge of groundwater with wells that dry up easily, poor availability of spare parts for repairs, gender inequality in WUCs with the involvement of men mostly for financial gains, the lack of enthusiasm, and more importantly, the ad hoc nature of each household's financial contributions. It seems that once a household is forced to seek an alternative water source because of breakage or water drying up, this in turn can weaken their motivation to contribute towards the repair of a specific water point.

Much effort on improving access to water during the Millennium Development Goals' (MDGs) mandate were strongly oriented towards attaining increased levels of coverage. In 2015, 91\% of people worldwide had access to an improved drinking water source compared to 76\% in 1990; however, most of the water sources considered as improved were not necessarily safe to drink [21]. Securing the longer-term sustainability of water supply systems took second place to achieving the targets for coverage [22,23]. As CBM is intended to create a relationship between the water point (WP) and the user population, it is not only the functionality of the physical infrastructure (the pumps and boreholes) that is of concern, but also the functionality of the water point committee charged with management responsibilities [24,25]. As such, two phases of WP development and management are invaluable within the practice-focused literature: a design and implementation phase, and a post-construction phase. The design and implementation phase is considered important for putting in place the social and technical preconditions for effective CBM $[18,26]$. At this stage, community "sensitization", participation, and training appear important determinants of the future operation and management of the system [27]. A study in Uganda indicated that WPC's are likely to fail when confronted with technical issues of operation and maintenance of water points which the committee itself has little or no control over, especially when they lack the required knowledge, skills, and resources at the community level [28]. 
Given that rural point water facilities target over 85 percent of Uganda's 34 million people, it is expected that more sound and conscious mechanisms for ensuring that CBM enhances its contribution to equitable and sustainable rural water services are put in place [29]. Some of the roles and responsibilities outlined in the Uganda Water Policy within the framework for the operation and maintenance of rural water supplies through the WPC include, among others, to mobilize the community to pay a monthly contribution towards operation and maintenance of the water facility, carry out routine preventive maintenance, and also to engage in major rehabilitations. Furthermore, the WPCs are also supposed to sensitize communities on good sanitation and hygiene practices so that the safe water chain could be maintained [30]. It is reported that rural water point functionality increased from 53\% in 2011 [31] to 84\% in 2017 [32]. Despite such significant progress, a recent mapping exercise conducted by the current study in two Parishes in Lwengo district recorded approximately $50 \%$ functionality of rural water points.

Ensuring the continued operation of water points, and in keeping with participatory theory, the WPC should also be a vehicle for empowering communities whilst bringing about greater equity of use $[33,34]$. However, WPC members do not acquire the knowledge and skills they need by default but require different types of training such as composition and management responsibilities of WPCs, undertaking minor repairs and rehabilitation activities, operation and maintenance of WPs, etc. [35]. This training in most cases is provided by ongoing projects/interventions by NGOs/project staff, the government, and in some cases, funding is provided for such training by local politicians. According to the Ugandan Water Policy, an important role of the WPC/WUC in rural water supply is to mobilize the community to pay a monthly contribution for operation and maintenance, to carry out preventative maintenance, and also to carry out major rehabilitation of water facilities. The aim of this paper therefore is threefold: (i) to identify the primary water source used by surveyed households and their participation towards community-managed water supply; (ii) to evaluate the types of capacity building training received by members of WUCs and who provided/funded such training; and (iii) to provide an evaluation of the technical, financial and institutional performance of WUCs in this area. Household income and mobilization are likely to have an impact on financial contributions to WUCs, which are considered in the current study based on two sets of hypotheses based on the role of the WPC as outlined in the Ugandan Water Policy. The first $\mathrm{H}_{\mathrm{o}}$ states that mobilization has no effect on households' financial contributions to a WUC, while mobilization does have an effect on households' financial contribution to a WUC is the $\mathrm{H}_{1}$. The second $\mathrm{H}_{0}$ states that there is no difference between better off and relatively poor households in their financial contributions to WUCs while the $\mathrm{H}_{1}$ states that there is a difference. These key questions will be considered in greater detail in the analysis together with other issues such as the type of water sources used by households in Makondo Parish, capacity building activities provided to members of WUCs and the performance of WUCs that are likely to influence the sustainability of community-managed water supply systems. An assessment of community water supplies such as this one, working through the lens of participation and capacity development in rural case study areas in Uganda as it relates to technical, financial, and institutional performance, is not just important but also timely in this Era of the Sustainable Development Goals.

\section{Conceptual Perspective: Capacity Building}

Essentially, by 2017, it was acknowledged that many of the hardware projects implemented to improve access to drinking water in developing countries, and sub-Saharan Africa in particular, had failed to meet their objectives [36]. The failure was partly due to weak operation, maintenance, and management of the infrastructure by water service providers, e.g., utilities [37]. Such interventions had wrongly assumed that the institutional framework in which infrastructural projects were to function was conducive or would develop automatically with time [38]. However, it became clear that the mere provision of hard infrastructure is not a "silver bullet" solution for water problems in developing countries, which were dominant during the 1980s (known as the International Decade of Drinking Water Supply and Sanitation [9]). That led to a shift towards a software conception 
of the water sector in the international development agenda through a series of conferences and communiques, including the 1990 Delhi Statement and the 1992 Dublin Principles [5].

This new philosophy consisted of putting institutional strengthening upfront, assuming that weak institutions are generally the main reason for the subsequent poor performance of a physical water infrastructure. Alaerts and Kaspersma [39] recommended that a multi-dimensional approach involving four interrelated levels—individual, organizational, enabling environment, and civil society—be considered for institutional and capacities development interventions. Capacity development can also take the form of education, organizational improvement, and awareness creation and understanding of water use and value by local communities $[36,40,41]$. Capacity development (CD) has been contextualized differently and our understanding of the term has evolved from narrow conceptualizations of capacity, with a focus on individuals or organizations [42], to an understanding that appreciates the systemic and multidimensional nature of capacity, focusing on the ability of human systems to perform, survive, and self-renew [43].

In the context of the water sector, Alaerts and Kasperma [39] have defined capacity accordingly as "the capability of a community or a society to identify and understand its development issues, to act to address these, and to learn from experience and accumulate knowledge for the future". Community-based water management is a holistic process through which people, organizations, and societies continually mobilize, maintain, adapt, and expand their ability to manage their own sustainable development; this is the meaning of "capacity development" within the context of German Technical Cooperation Agency (GTZ) [44]. In practice, however, there is no consensus about how knowledge and capacity development (KCD) should be assessed and there are many challenges associated with capacity development assessment [45]. These include, among others, the difficulty of a unified definition of the concept of capacity development, its complex nature that makes it difficult to operationalize and cover all relevant aspects, and the existences of competing capacity evaluation approaches [39,46].

In 1991, the Delft Declaration [47] defined CD as consisting of three main elements, namely: (i) creating an enabling environment with appropriate policy and legal frameworks; (ii) institutional development, including community participation; and (iii) human resources development and strengthening of managerial systems. Since then, consensus has been growing among academics and development practitioners about three nested levels at which KCD takes place: that of the individual, of the organization, and of the enabling environment $[39,48-50]$. The CBM model in Uganda operates on the idea that when WPCs are functional (when they meet regularly, collect funds for O\&M, ensure proper sanitation and hygiene at water sources, report or handle hand pump breakdowns, and formulate and enforce bye-laws) high levels of functional sustainability of water sources that meet high access, equity and efficiency standards are realized [29]. As such, capacity development in this study will be considered by looking at the training received by members of the WPCs in rural Uganda and at how often these committees meet to deal with issues regarding water.

\section{Materials and Methods}

\subsection{Study Areas}

The case study area in rural Uganda is located in Makondo Parish, which was selected for the WaterSPOUTT project; this project has as its objective to transform access to safe drinking water through integrated social sciences, education, and solar technologies in vulnerable communities in Africa. Makondo Parish was selected based on the team's previous work ten years ago under the "Water is Life" program on governance. The WaterSPOUTT programme provided the opportunity to do a return visit to see how the WUCs were functioning. For a full report, see "A Socio-Spatial Survey of Water Issues in Makondo Parish, Uganda" [17]. The Parish is situated in rural Lwengo District that was carved out of the former Masaka District and is located approximately $194 \mathrm{~km}$ from Kampala, the nation's capital city (Figure 1). Makondo Parish has 1726 households with an estimated 
population of 8193 inhabitants, many of whom derive their livelihoods from crop and livestock farming typical of rural communities in most African countries [51]. All 17 villages in the parish were part of the study and include: Makondo, Kiguluka, Kiganjo, Misaana, Kijjajasi, Kayunga, Wajjinja, Luyiiyi Kaate, Kyamukama, Luyiiyi Protazio, Kibuye, Kiteredde, Micunda, Kabuyoga, Kitabaazi, Kanyogoga, and Kiyumbakimu. The livelihood activities across these villages are the same and are dominated by farm households that depend on subsistence farming. The major crops grown in the Parish are plantain bananas ("matooke"), coffee, cassava, Irish potatoes, sweet potatoes, beans, maize, groundnuts, sorghum, rice, and finger millet. The major livestock kept included cattle, sheep, goats, and chicken [52].

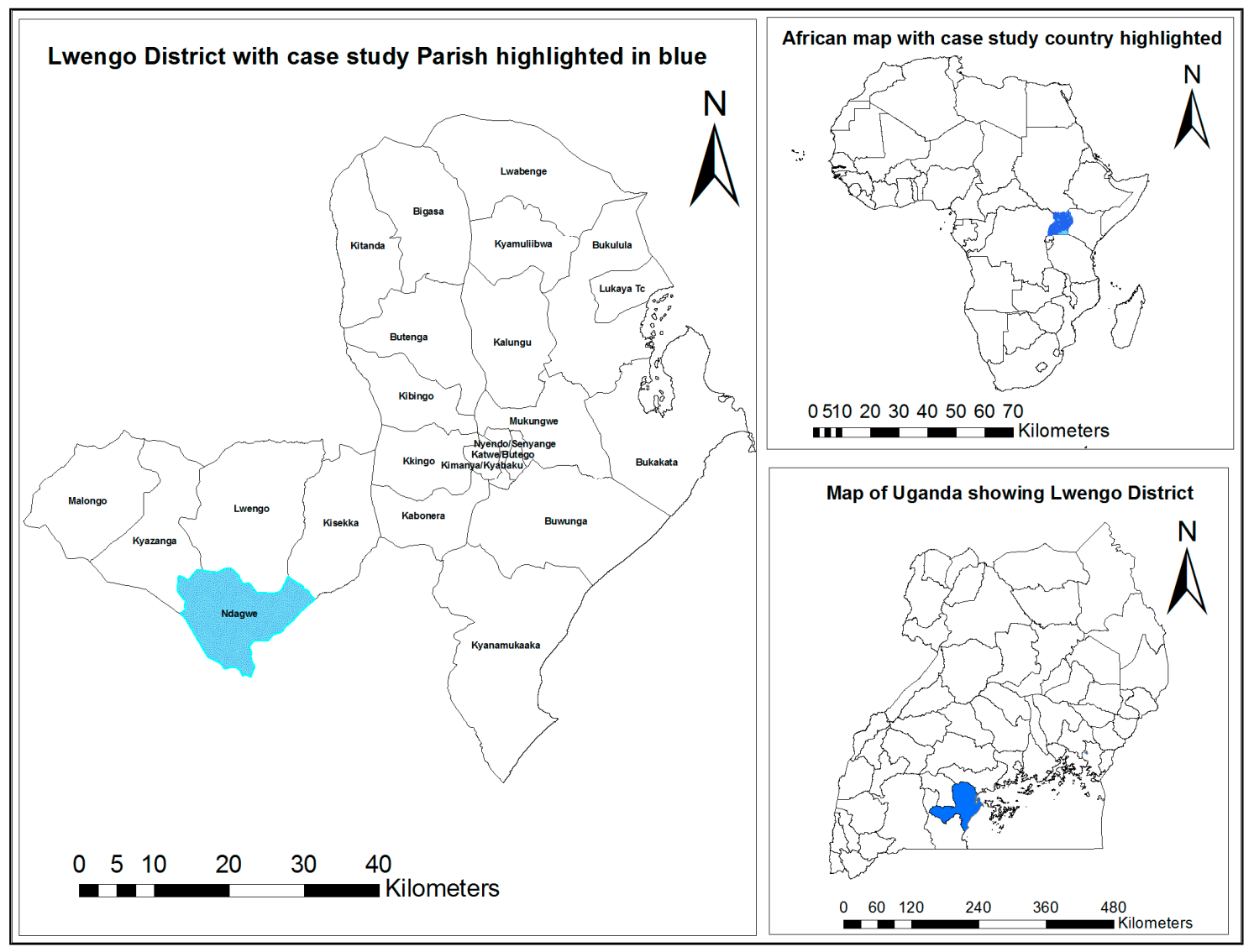

Figure 1. Map of Uganda showing the case study location in Lwengo District.

The landscape in Makondo has typical savannah characteristics dominated by shrubs that are interspaced with grasses. Furthermore, the parish has several hummocks dissected by streams, rivers and swamps, including Katonga and Kanana rivers that drain into Lake Victoria to the east. Seasonal surface runoff from rainfall is the major recharge, although most streams are dry for much of the year [53]. Makondo Parish is situated between the savannah tropical climate and the semi-arid climate with temperatures ranging from $26^{\circ} \mathrm{C}$ to $29^{\circ} \mathrm{C}$. The Parish also benefits from two periods of rainy seasons (March-May and September-November) and two dry spells (January-February and June-August), with an annual average rainfall amount of $950 \mathrm{~mm}$ per annum. However, due to climate variability and change, the Parish experiences changes and fluctuations in climatic conditions that are reflected in longer periods of droughts and erratic rainfall [54].

\subsection{Data Collection and Analysis}

The rural site selections were based on locating communities surrounding ponds, streams, springs, shallow wells, and boreholes that were in use as sources of domestic water supply. Members of the research team had engaged in previous interventions/studies on governance in the selected 
communities called "Water is Life", and this proved to be the entry point to this community. This was the team's previous work ten years ago on governance and the WUCs, and this was a return visit to see how the WUCs were functioning. In the previous survey carried out by some members of this team in the same location, published in 2013, it recorded that $35 \%$ of the surveyed households used unimproved sources such as ponds, open or hand-dug wells, and unprotected springs as their primary sources of water [16].

This current study began with a shared dialogue workshop (SDW) with opinion leaders and other stakeholders (particularly women) on water in Makondo Parish. Within the context of WaterSPOUTT, a SDW is a forum that brings academics as well as technicians, educators, politicians, practitioners, community leaders, and household members together at regular intervals to identify challenges and obstacles to, and opportunities for, the uptake of solar technologies at the household, community, and regional level. Taking these criteria into consideration, a SDW was conducted on 21 October 2016 at the Makondo Health Centre run by the Medical Missionaries of Mary (MMMs) and was facilitated by four researchers from Makerere University. The workshop was conducted entirely in the local vernacular (Luganda). Some of the issues discussed were current water technologies and water sources used in the Parish, and challenges associated with community management of water supply systems and access to water. Given that the livelihood activities are the same across the 17 villages, namely dependence on subsistence farming and the use of similar water sources, a random sampling method was applied. A total of 642 households in the Parish was surveyed and 30\% of the households stated that they had a member belonging to a WUC.

Some of the questions asked during the household survey included water sources used; types of contributions made by households during the last 12 months prior to the survey such as financial contributions, land for water points, labour, etc.; estimated monthly income earned; and financial contributions and pattern of payment to the WUCs. One hundred and ninety-two households who had members (30\%) belonging to a WUC were asked to provide information on the different types of training received, on who provided funding for training, and finally the perceptions on the technical, financial, and institutional performance of the WUCs. Therefore, the analysis of the technical and institutional performance of the WUCs was based on the information gathered from the $30 \%$ surveyed households who had a member in a WUC while the financial performance was based on the 642 surveyed households.

The complementary qualitative data from the SDW was analyzed using verbatim transcription and Wordstat 7 (PROVALIS RESEARCH, Montreal, QC, Canada) content analysis software that enabled us to identify the key themes emanating from the discussion. The Wordstat 7 software was used because of its ability to find themes or relationships in verbatim responses, focus group transcripts, or other text sources. It involved four main steps [55] as follows: (1) identification of the main themes; (2) attributing codes to the main themes; (3) classification of responses under the main themes; and (4) integration of themes and responses into narratives. The presence of two categorical variables in the data allowed for the chi-square test of independence to be applied with the aim of testing for a significant relationship or association using the Statistical Package for Social Science (SPSS) version 23 (IBM Corp. Released 2015. IBM SPSS Statistics for Windows, Version 23.0. Armonk, NY, USA). The first null hypothesis was that there was no difference between household mobilization and their financial contributions to the WUC. The second null hypothesis was that there was no association between household contributions to WUC and monthly income earned. In addition, descriptive methods were also used as the results are presented in the form of tables, pie graphs, and column charts.

\section{Results and Discussion}

\subsection{Households Primary Water Source and Participation in a WUC}

The majority $(41.7 \%)$ of the surveyed households across the case study area used an unprotected source such as open ponds and rivers. A total of $27.6 \%$ of surveyed households used water from 
shallow wells, a source exposed to high risk of contamination and also dries-up easily, where $20.4 \%$ used boreholes, 5.6\% used water from springs, and 4.7\% harvested rainwater (Figure 2). An example of an open pond used by households in Makondo was identified during a visit to the study area (see Figure A1). While 30\% (192 of 642 of surveyed households) of households participated by having a member on the WUC as already stated, there were other contributions made by households. Forty-eight percent of households made financial contributions, $26.9 \%$ provided labour, $18.5 \%$ engaged in meetings during which they contributed their ideas, while a minuscule $6.1 \%$ and $0.5 \%$ mentioned "other" and the provision of land, respectively (Figure 3).

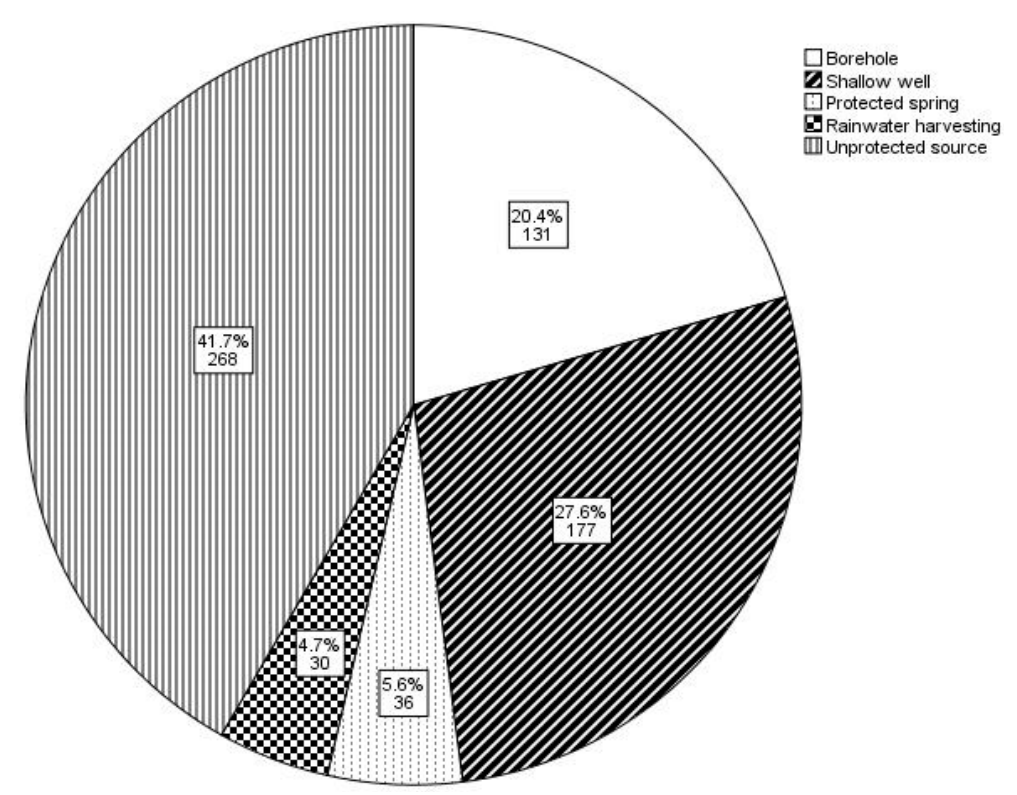

Figure 2. Primary water source used by surveyed households in rural Uganda.

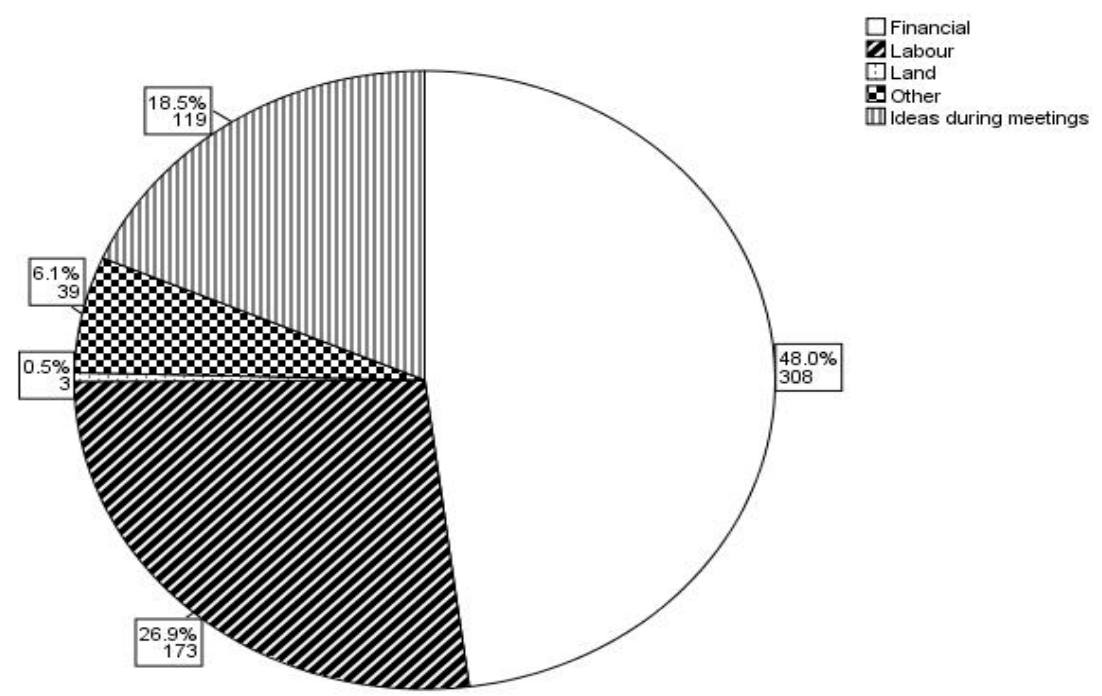

Figure 3. Kind of contribution made by households towards a WUC.

One of the roles of the WUC is to mobilize the community members towards their monthly financial contributions that are to be used for the operation and maintenance of the water point. The chi-square test indicated that mobilization did have an impact on household financial contributions to a WUC because the $\mathrm{H}_{0}$ was rejected in favour of the $\mathrm{H}_{1}$ given that $p<$ alpha (Table 1 ). 
Table 1. A cross-tabulation between mobilization of households in the case study communities versus those that made contributions to the WUC.

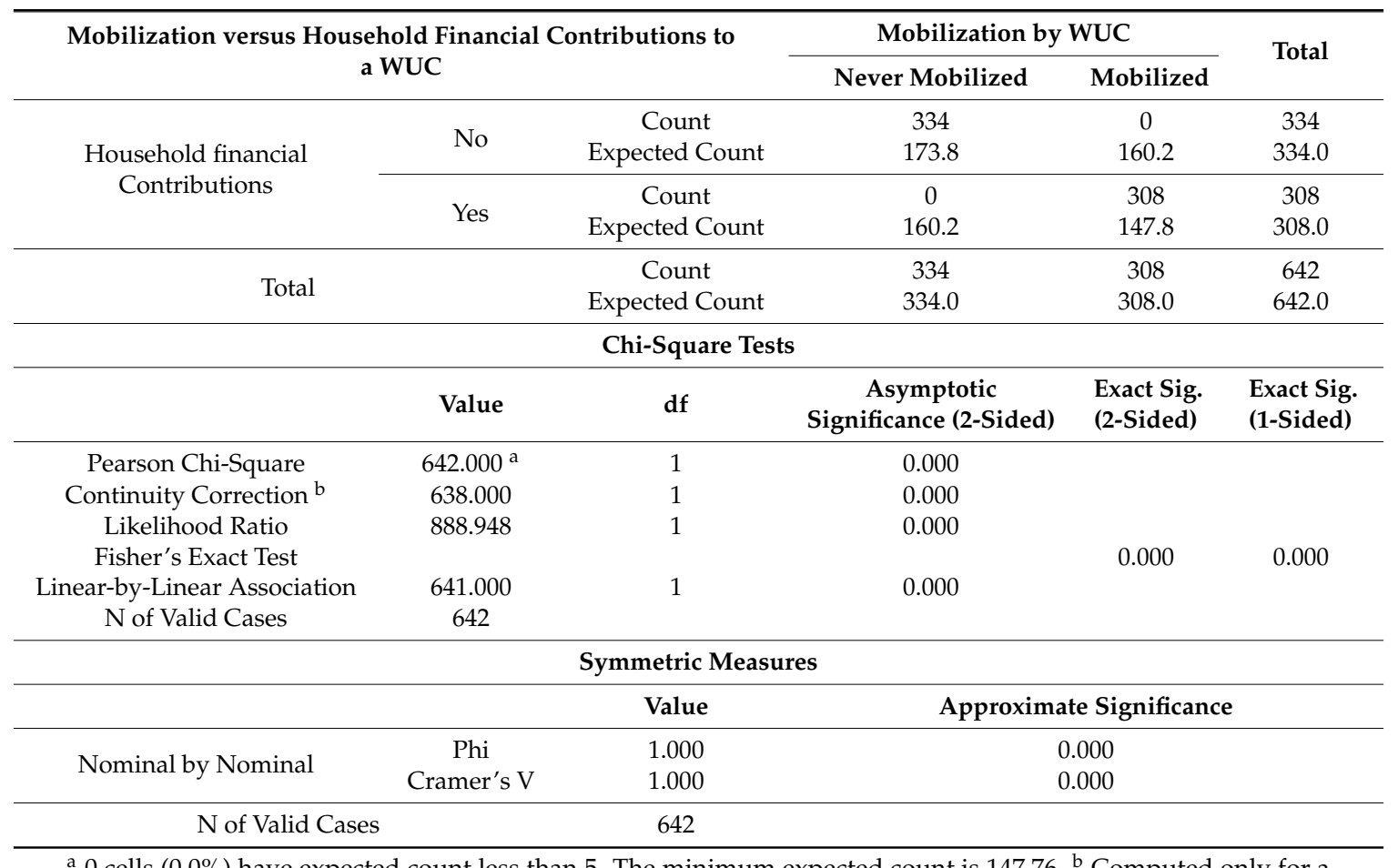

0 cells $(0.0 \%)$ have expected count less than 5 . The minimum expected count is $147.76 .{ }^{\mathrm{b}}$ Computed only for a $2 \times 2$ table.

Furthermore, another statistical test was conducted with the $\mathrm{H}_{0}$ to find that there was no difference between better off and relatively poor households in their contributions to a WUC. The test result failed to reject the $\mathrm{H}_{0}$ given that $p>$ alpha (Table 2). It, therefore, revealed that there was no difference between better off and relatively poor households in their contributions to a WUC, which is an indication that other factors, such as the lack of maintenance resulting in a high rate of non-functionality, use of alternative water sources during prolonged period of breakdown, and the politicization of water, were identified during the SDW that took place in Makondo Parish to influence such decisions. Households were likely to make monthly contributions especially when the water point was reliable and not because they occupied a relatively much better financial situation compared to other households. A previous study specifically on gender and governance in this case study area by Asaba et al. [56] indicated that the frequent breakdown of pumps and slow repairs left community members with the feeling that operation and maintenance fees were not worth paying, which is an indication that poverty is only part of the problem. According to this same study, village chairpersons in these communities had in the past allocated access to especially improved water sources to certain individuals and households based on personal relationships, even when O\&M fees had not been paid. Therefore, improvement of operational efficiency could be served by a more enabling institutional set-up that allowed for transparency and accountability of collected funds, especially to community members, which is a view supported by Breeveld et al. [57].

\subsection{Capacity Building Activities Provided to WUCs}

One of the focuses of this study was the different types of training received by the 192 households who had a member in a WUC and who provided or funded such training across the case study villages. On the formation of a WUC, of the 192 households who had these members, $42.7 \%$ indicated the training given to their member of the WUC was provided by NGOs/project staff, while $34.9 \%$ mentioned the government. It should be noted that $12 \%$ of the respondents said no training was 
provided for the formation of a WUC since they refer to initiatives that were driven by community members. Local politicians, when compared to project staff, engaged differently on certain issues pertaining to the community water supply. Local politicians provided funding through the district office in the Ministry of Water and Environment, which has the capacity/technical skills to provide training to WUCs. An example of such training in our study was the formation of WUCs, as reported by $10.4 \%$ of the respondents (see Table 3 ).

Table 2. Cross-tabulation to identify if an association existed between household monthly income earned and their contributions made to the WUC.

\begin{tabular}{|c|c|c|c|c|c|c|c|c|}
\hline \multirow{2}{*}{\multicolumn{3}{|c|}{ Household Income versus Contribution to a WUC }} & \multicolumn{5}{|c|}{ Estimated Monthly Household Income Earned } & \multirow{2}{*}{ Total } \\
\hline & & & 0 & $1-100,000$ & $101,000-350,000$ & $351,000-750,000$ & $751,000-2,000,000$ & \\
\hline \multirow{3}{*}{$\begin{array}{l}\text { Household financial } \\
\text { Contribution }\end{array}$} & \multirow{2}{*}{ No } & Count & 35 & 201 & 65 & 24 & 9 & 334 \\
\hline & & Expected Count & 28.6 & 200.3 & 69.2 & 28.1 & 7.8 & 334.0 \\
\hline & Yes & $\begin{array}{c}\text { Count } \\
\text { Expected Count }\end{array}$ & $\begin{array}{c}20 \\
26.4\end{array}$ & $\begin{array}{c}184 \\
184.7\end{array}$ & $\begin{array}{c}68 \\
63.8\end{array}$ & $\begin{array}{c}30 \\
25.9\end{array}$ & $\begin{array}{c}6 \\
7.2\end{array}$ & $\begin{array}{c}308 \\
308.0\end{array}$ \\
\hline \multirow[b]{2}{*}{ Total } & & Count & 55 & 385 & 133 & 54 & 15 & 642 \\
\hline & & Expected Count & 55.0 & 385.0 & $\begin{array}{l}133 \\
133.0\end{array}$ & 54.0 & 15.0 & 642.0 \\
\hline \multicolumn{9}{|c|}{ Chi-Square Tests } \\
\hline & Value & df & \multicolumn{5}{|c|}{ Asymptotic Significance (2-Sided) } & \\
\hline Pearson Chi-Square & $5.131^{\mathrm{a}}$ & 4 & \multicolumn{6}{|c|}{0.274} \\
\hline Likelihood Ratio & 5.181 & 4 & \multicolumn{6}{|c|}{0.269} \\
\hline Linear-by-Linear Association & 2.021 & 1 & \multicolumn{6}{|c|}{0.155} \\
\hline $\mathrm{N}$ of Valid Cases & 642 & & & & & & & \\
\hline
\end{tabular}

Table 3. Type of training activities provided/funded by different stakeholders to ensure the establishment and functioning of WUCs in case study communities.

\begin{tabular}{|c|c|c|c|}
\hline Activity/Intervention & Trainer/Funder & Frequency & Percentage \\
\hline \multirow{5}{*}{ Formation of WUC } & Government & 67 & $34.9 \%$ \\
\hline & $\mathrm{NGO} /$ project staff & 82 & $42.7 \%$ \\
\hline & Local politicians & 20 & $10.4 \%$ \\
\hline & No training/funding & 23 & $12.0 \%$ \\
\hline & Total & $\mathrm{N}=192$ & $100.0 \%$ \\
\hline \multirow{5}{*}{ O\&M of Water Point } & Government & 14 & $7.3 \%$ \\
\hline & NGO/project staff & 118 & $61.5 \%$ \\
\hline & Local politicians & 6 & $3.1 \%$ \\
\hline & No training/funding & 54 & $28.1 \%$ \\
\hline & Total & $\mathrm{N}=192$ & $100.0 \%$ \\
\hline \multirow{5}{*}{ Undertaking Minor Repairs } & Government & 10 & $5.2 \%$ \\
\hline & $\mathrm{NGO} /$ project staff & 120 & $62.5 \%$ \\
\hline & Local politicians & 0 & $0.0 \%$ \\
\hline & No training/funding & 62 & $32.3 \%$ \\
\hline & Total & $N=192$ & $100.0 \%$ \\
\hline \multirow{5}{*}{ Forming and Enforcing Bylaws } & Government & 102 & $53.1 \%$ \\
\hline & NGO/project staff & 30 & $15.6 \%$ \\
\hline & Local politicians & 60 & $31.3 \%$ \\
\hline & No training/funding & 0 & $0.0 \%$ \\
\hline & Total & $N=192$ & $100.0 \%$ \\
\hline \multirow{5}{*}{ Management of Collected Funds } & Government & 111 & $57.8 \%$ \\
\hline & NGO/project staff & 67 & $35.0 \%$ \\
\hline & Local politicians & 14 & $7.2 \%$ \\
\hline & No training/funding & 0 & $0.0 \%$ \\
\hline & Total & $N=192$ & $100.0 \%$ \\
\hline
\end{tabular}

Operation and maintenance (O\&M) was key to the success of most water points that were technology-oriented notwithstanding how simplified the design of some of them might appear. 
The Afridev hand pump, which is easy to install and has excellent potential for community-based maintenance [8], was the dominant water technology implemented in Makondo Parish during the last fifteen years. However, a previous study reported that $50 \%$ of these pumps in Makondo Parish were non-functional due to a lack of maintenance [16]. An overwhelming $61.5 \%$ of the respondents reported that training on O\&M was provided by NGOs/project staff. This was not surprising because most of the hardware water projects/interventions in most rural areas, especially in developing countries and Africa in particular, are provided by NGOs with funding from different donors from the West. These technologies, in most cases, are brought into the communities that have to be trained on how to undertake preventative maintenance, minor and major repairs, and even rehabilitation activities. Those communities that depend on other sources of water, such as rivers, springs, and wells, might not require a specific knowledge or skill to operate and maintain such a source. However, the use of local knowledge systems has been relevant in the protection of these sources with the use of locally available materials such as wood to protect rivers, springs, wells, etc. Kaplan [58] emphasises that CD is an endogenous process that external interventions can only support, not steer. This is because the practice of $\mathrm{CD}$ in the development arena that intends to achieve sustainability especially in the Era of the Sustainable Development Goals should be capable to move from the narrow vision that conceives $\mathrm{CD}$ as a mechanical process of transfer of external knowledge and/or resources from individuals in the Global North to the Global South. Although capacity resides internally, and its development has to be internally driven as well, some external drivers, such as influencing a proactive policy process on water governance, technology transfer, financial support through international development projects, and training and capacity development activities, can catalyse, initiate, and help shape the internal ones [59]. An earlier study in Makondo Parish in Uganda by Asaba [60] showed that men were more enthusiastic about attending pre-construction meetings and related activities of NGOs for two reasons: high expectations at the beginning of projects and financial benefits. The financial benefits relate to "transport allowance" and "lunch allowance," which according to community members, were rarely provided by the Sub County and District service providers [60]. This explains why community members, especially men, avoided most of the training organized by government service providers.

The need to undertake minor repair often arose especially with the introduction of hardware technologies in communities to improve access to safe water. A total of $61.5 \%$ respondents indicated that such training was provided by NGOs/project staff, while $5.2 \%$ mentioned the government (Table 3 ). The role of community mechanics that are trained by NGOs/project staff were of great importance. However, training local mechanics to undertake minor repairs was just part of the solution because the local availability of spare parts and their cost was also important. The failure attributed to most water technologies in sub-Saharan Africa (SSA) was partly due to weak operation and management of the water infrastructure by WUCs [37]. In relation to training provided towards the formation and enforcement of bylaws, the government dominated as reported by $53.1 \%$ of households who had WUC members, followed by local politicians. The government, through its district authorities, engaged in governance at the local level and so did local politicians who were representatives of their communities. Finally, $57.8 \%$ and $35 \%$ of the respondents reported that training on the management of collected funds were provided by the government and NGOs/project staffs, respectively (see Table 3). The engagement of different stakeholders in providing training, or funding such training, to ensure the effective performance of the WUC further highlights the importance of partnership in the water sector [61]. Achieving goals and maintaining a harmonious relationship is key in partnership between the community, government, NGOs, and private sector. This was because regardless of the expertise and competence of the external partner, unless the interventions were skilfully facilitated with commitment of the local partner, the intended changes were not likely to occur [62].

\subsection{Perceptions on the Performance of WUCs}

The final question focused on whether community management generated the expected levels of technical and financial performance depending on the type of water source used, e.g., boreholes, 
open wells with pumps, etc. To maintain high levels of enthusiasm within WUCs and the sustainability of community-based water infrastructures would require much better technical, financial, and institutional performance of WUCs. These issues are discussed in further details in this section.

\subsubsection{Technical Performance}

Of the 192 households who had someone who was a member of a WUC, 23\% reported to have undertaken minor repairs at the water point during the last 12 months prior to the survey, which occurred between June to September 2017 (see Figure 4). Community management was expected to be characterized by regular maintenance, using locally held stocks of spare parts and local skills. However, there was no indication of preventative maintenance. Bruns [63] suggested recipient organizations/communities should put in more preventative maintenance efforts to avoid major breakdowns. Three studies in SSA indicated that operational failure rates between 30-60\% were common in the sub-region [12-14]. According to another study, one-quarter of new water points became non-functional within two years of installation [15]. The figures for undertaking minor repairs were quite low (Figure 4) despite the presence of an abandoned borehole in Makondo (see Figure A2). This borehole had not been functional for over five years despite a series of repairs undertaken by the local pump mechanic according to one participant during a field visit in May 2018. Given the very weak level of technical skills, the role of the community mechanic (especially with additional training to handle both minor and major repairs of boreholes) was critically important, which is a view supported by Wehn de Montalvo and Alaerts [35]. According to a key leading local during the field visit in May 2018, there was no need for preventive maintenance of the borehole, which functioned without any problem for over four years. Such findings corroborate those of a study conducted in Malawi in which local pump mechanics were reluctant to conduct preventive maintenance because many well-built water points, especially boreholes, function for many years with no problem [9] (p. 268).

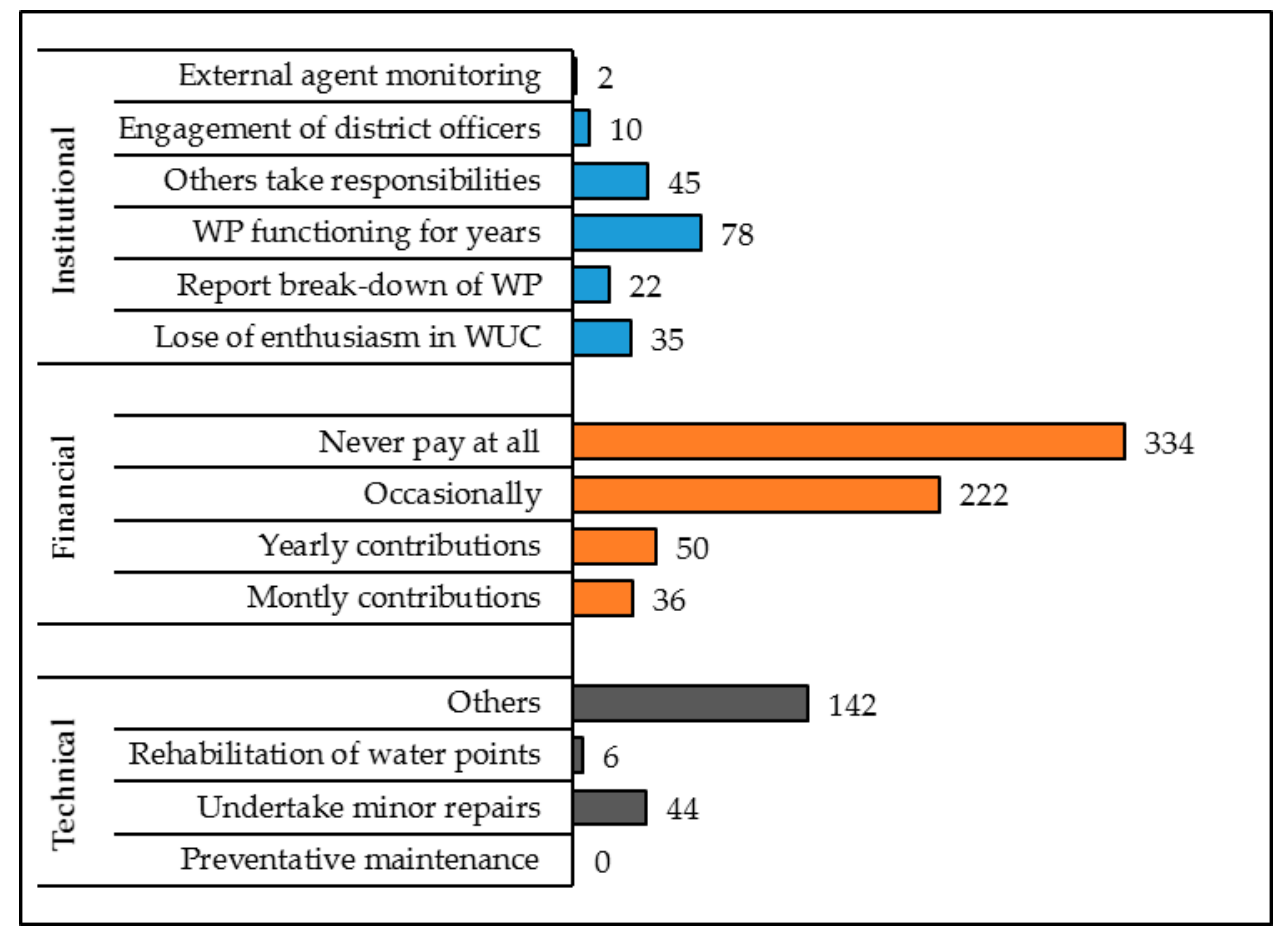

Figure 4. Technical, financial, and institutional performance of WUC in the case study area.

The category "others" pertaining to technical performance, as reported by $74 \%$ of members in WUCs (Figure 4), includes the following: construction of wells, and the protection of ponds and springs with locally available materials such as woods. Asaba et al. [56], in their study in Makondo Parish, revealed that men carried bricks, gravel, and other materials during the construction or repair 
of improved water sources, while women were engaged in picking up rubbish lying around open wells, and slashing grass and surrounding bushes. The use of local knowledge systems was invaluable in protecting water sources, such as open ponds, springs, shallow wells, and streams, given that unimproved water sources were commonly used across the rural case study areas in Uganda. A greater challenge that community members mentioned during the first SDW at Makondo was the impact of climate change on water resources as some ponds and springs were not available for use towards the end of the dry season. Such occurrences according to the SDW were frequent, but this was not the situation some ten years ago. Inadequate resources for rehabilitation activities to be carried out was one of the technical challenges faced by the WUCs and the district officers of the Ministry of Water and Environment in Uganda. Financial and material resources, and skills, were needed for rehabilitation of boreholes, for example the availability of spare parts, the finance to pay for them, and the technical skill to replace them. Aside from rehabilitation activities, capacity development could take different forms, such as education, organizational improvement, awareness creation, and an understanding of water use and value by local communities, which is an approach supported by several studies [36,39-41].

\subsubsection{Financial Performance}

Out of the 642 surveyed households, $52 \%(\mathrm{n}=334)$ had never made any financial contributions to the WUCs, while $48 \%$ had made such contributions ranging from monthly $(5.6 \%)$, once a year $(7.8 \%)$, and occasional (34.6\%) (see Figure 4). Despite the existence of WUCs across the villages in the case study location, the predominance of water sources that required very little or no financial resources to maintain was a further justification as to why monthly contributions had the least figure. On the other hand, households that did not contribute financially were likely to have contributed either land, labour, or even ideas during meetings, which were important for the maintenance of water sources such as ponds, shallow wells, springs, and even streams. The low payment rate, therefore, cannot be linked to household poverty, but to the types of water sources used. It should be noted that boreholes were much more expensive to maintain than shallow wells, and was one of the dominant sources of water in these communities and broke down frequently. The monthly amount that households were expected to pay ranged between 500 to 1000 UGX, but in reality, these monthly fees were rarely paid by the water point users, especially men. Even when they did, such payments were made occasionally when the pump had broken and needed to be repaired. Our findings were contrary to that of a study conducted in rural Malawi in which poverty and inappropriate management of collected funds were both cited as the reasons associated with the poor financial performance of WUCs [9]. Rather, household heads, especially among men who have a personal relationship with the chairperson or other members of the WUC, enjoyed some privilege and perhaps did not make their monthly contributions as indicated in an earlier study conducted in Makondo Parish [56]. Additionally, the predominance of unimproved access by households given the low functionality rate of improved sources with less than $50 \%$ functionality [16], such as wells with a pump and the Afridev hand pump, further weakened their financial commitments to WUCs.

\subsubsection{Institutional Performance}

Community-based management as a public sector reform seems to be lagging behind in delivering the expected benefits in technical and financial performance. Rather, this model seems in reality to operate contrary to its original agenda since funds were instead collected on an ad hoc basis after breakdown occurred. The question arose as to whether community management had strengthened institutional capacity especially at the local and district levels. Of the 192 members of WUCs across the 17 case study villages, $18.2 \%(n=35)$ indicated a loss of enthusiasm (see Figure 4). Institutions provided the context within which actors could interact, especially when they changed over time as a result of interactions among multiple actors without losing focus on why they were created in the first instance [57]. Issues, such as lack of enthusiasm among some members of the WUCs and even community members, might occur when water points broke down frequently, boreholes were 
abandoned, water points had low functionality, and when financial commitment from the community and government for water points rehabilitation was lacking. A direct consequence on the WUCs was a natural decline of its membership as supported by an earlier study in Malawi [9].

"Others" were mentioned to have taken certain responsibilities in relation to the WUCs as reported by $23.5 \%$. Local politicians were cited by the majority of the respondents as people who provided help especially during periods closer to elections. The politicization of water for personal gains implied help might not come when really needed. Even when it did come through such means, it could not effectively address the water needs of communities. Alaerts and Kaspersma [39] stated that the institutional and organizational environments within which individuals operate are a key part of water sector capacity development. Engagement of the government through its district officers of the Ministry of Water and Environment wass very low (as perceived by only $5.2 \%$ of the 192 WUC members) and the report of breakdown of water points (11.5\%) for rehabilitation might not have secured the required attention from the district office (see Figure 4 ). However, $40.6 \%$ of the water points had been functioning for several years. The basic principles behind community-based management, such as having a major role in the development, ownership of the water system/facility, and overall responsibility for its O\&M, as stated by Harvey and Reed [7], seems to have been given proper attention.

\section{Conclusions and Future Perspective}

This study addressed the role of participation and capacity development in community-managed water supply systems in rural Uganda. Household interviews conducted across the 17 case study villages in the Makondo Parish revealed that a majority of the households used an unprotected source of water, such as shallow wells, open ponds, and rivers, that were exposed to a high risk of contamination. Contributions towards community water management were made in the form of finance, labour, land, and even ideas during meetings. Regarding financial contribution to the WUCs, $52 \%$ of the surveyed households had never made any payment, and reasons cited were that such households were located in communities that depended on water sources such as ponds, springs, rivers, rainwater, and shallow wells. Additionally, better off and relatively poor households did not differ significantly in their financial contributions made to WUCs. This result corroborated the information gathered during the SDW, which indicated that lack of maintenance resulting in a high rate of non-functionality of boreholes, use of alternative water sources during prolonged period of breakdown, and the politicization of water influenced household financial contributions to WUCs. Aside from these factors that were cited as reasons for non-payment of the monthly levy to the WUCs, even a majority of the households who made such payments did so on an ad hoc basis, but particularly during the breakdown of boreholes. Such an approach ran contrary to the initial objectives of community management, which was supposed to create a sense of ownership to the technology and build capacity within the recipient community to enable them to secure and manage funds for O\&M. One of the weaknesses of relying on occasional financial contributions was that preventative maintenance was not done because host communities do not see it as a priority. The outcome of only occasional contributions were abandoned boreholes in the communities, which then raised questions about the technical and institutional performance of the WUCs in engaging community members to make their full financial contribution.

Furthermore, the rehabilitation of water points was very low in the study area and the politicization of water made it difficult for transparency and accountability, even in the so much praised community-management model. Capacity development, be it through the different types of training or sensitization campaigns is not an event but a process. Such a process can only be effective when its goals are realistic and can easily be measured. For example, the $84 \%$ performance of rural water supply according to the 2017 report of the Ministry of Water and Environment can easily be criticized because a nation-wide study masks the low functionality rate that is evident in specific rural areas. For example, approximately $50 \%$ of the water points in our case study area were 
functional. Therefore, ensuring the continued functionality of the water points, in addition to those that have been abandoned and those that will be constructed in the near future, will require effective technical, institutional, and financial performance for preventative maintenance and rehabilitation exercises. Many scholars and development practitioners during the last decade have been advocating for approaches that could drive a change in behavior in order to ensure the sustainable use of water technologies. In fact, capacity building components are now an integral part of development aid and or development interventions. However, behavior change takes time and will require an ongoing learning-by-doing process that effectively engages community members and institutions at different levels while creating partnerships.

Author Contributions: The survey design upon which this article is based was led by G.H.F., PI of the Social Science Work package of WaterSPOUTT and is derived in part from the Water is Life Project survey led by G.H.F. (and Ronaldo Munck) and designed by R.A.B. (and Firminus Mugumya). “Conceptualization, G.H.F. and D.E.; Methodology, G.H.F., D.E., C.K. and R.A.B.; Software, D.E.; Validation, D.E. and G.H.F.; Formal Analysis, D.E.; Investigation, D.E., G.H.F., C.K. and R.A.B.; Resources, D.E., G.H.F., C.K. and R.A.B.; Data Curation, D.E.; Writing-Original Draft Preparation, D.E.; Writing-Review \& Editing, D.E., G.H.F., C.K. and R.A.B.; Visualization, D.E., G.H.F., C.K. and R.A.B.; Supervision, G.H.F. and D.E.; Project Administration, G.H.F.

Funding: This research was funded by [the European Commission H2020-Water-5c-2015 awarded to the WATERSPOUTT Project] grant number [GA 688928].

Acknowledgments: We would like to thank our collaborators at Makerere University, Uganda for organizing and carrying out the Shared Dialogue Workshop (SWD) and the fieldwork for this study. Lastly, we are thankful to all the stakeholders and community member for the time taken out to participate in the SDW and baseline survey in Makondo Parish.

Conflicts of Interest: The authors declare no conflict of interest.

\section{Appendix A}

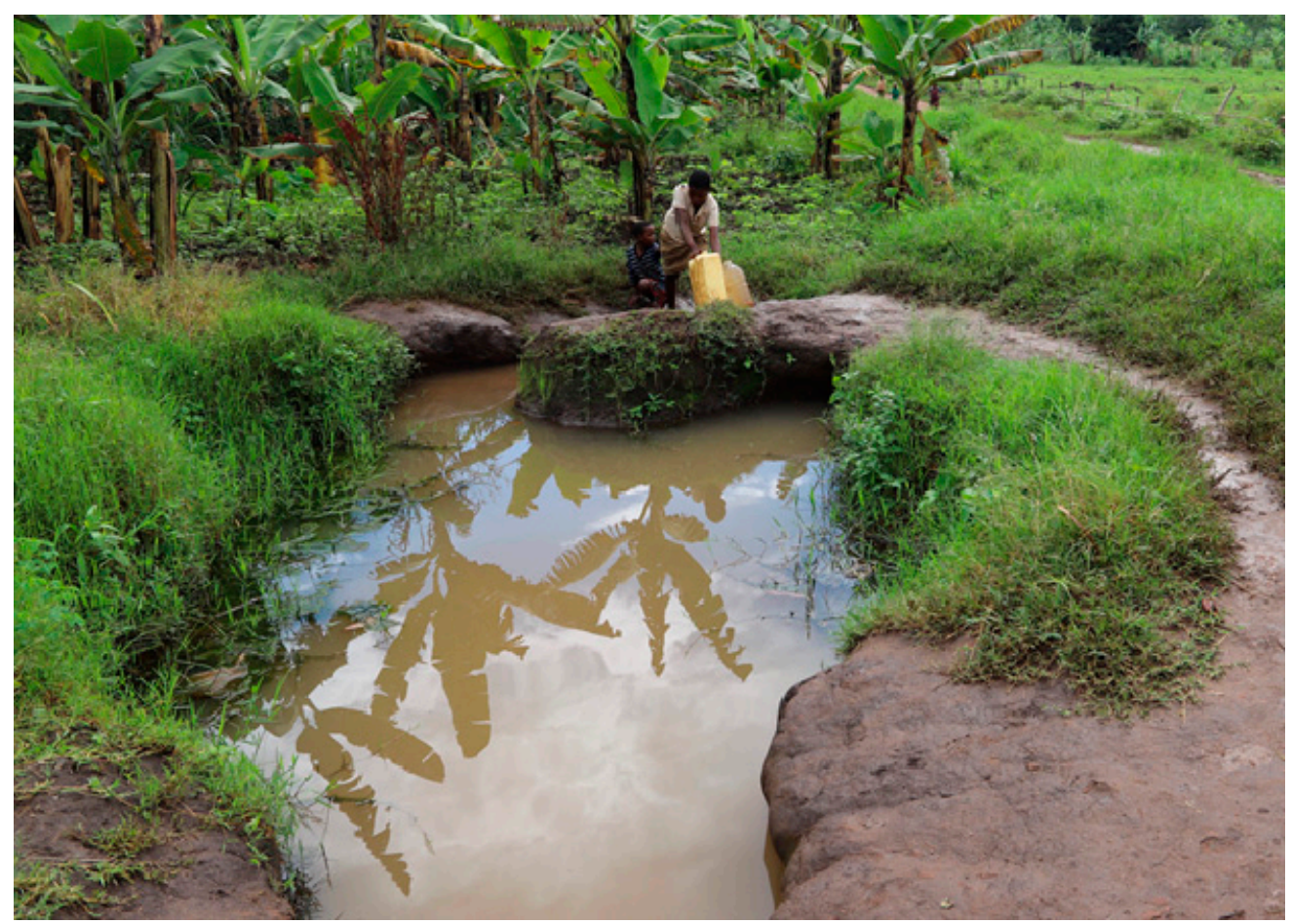

Figure A1. An open pond used by households in Makondo Parish. 

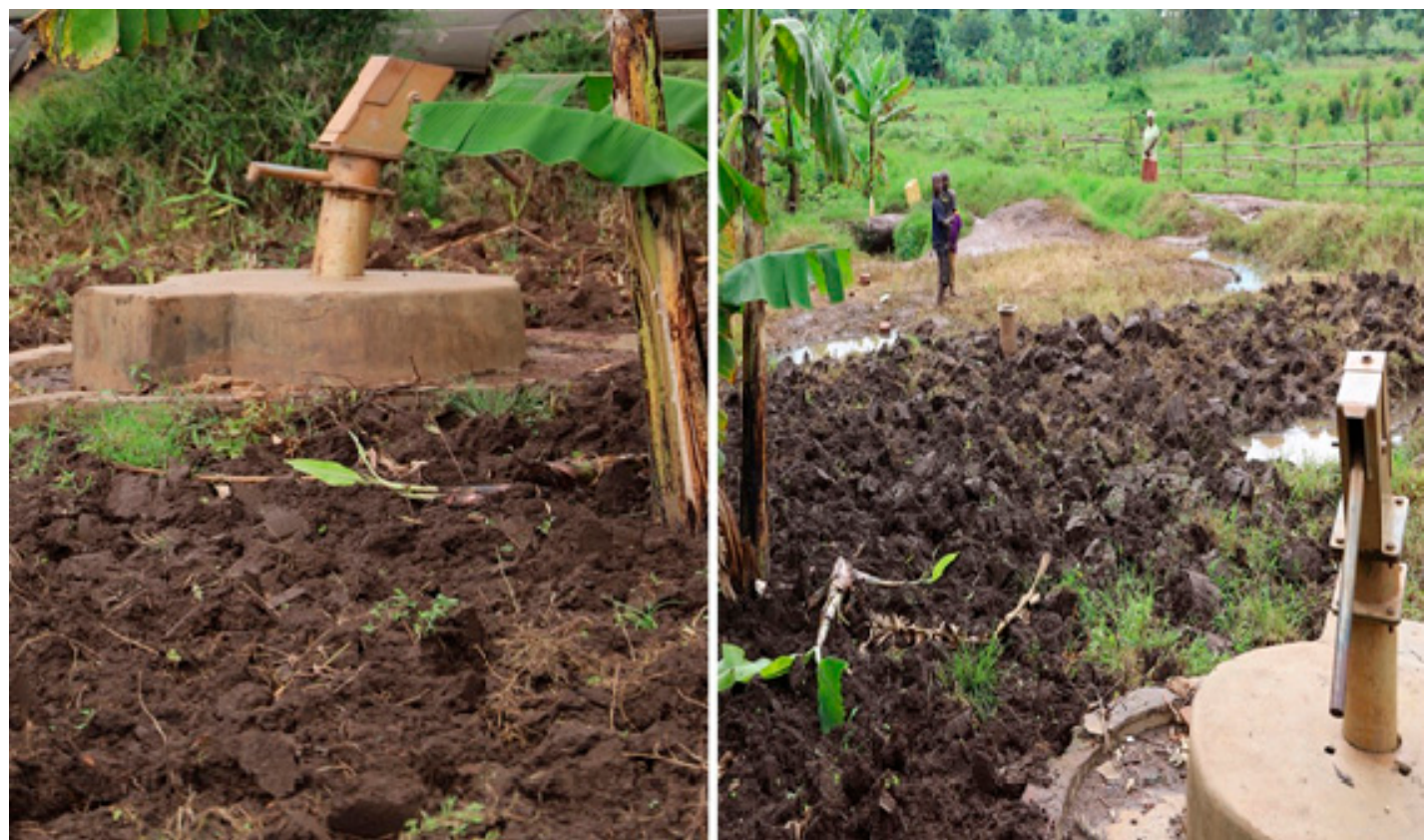

Figure A2. An abandoned borehole very close to the "arise and shine" primary school in Makondo.

\section{References}

1. Whaley, L.; Cleaver, F. Can 'functionality' save the community management model of rural water supply? Water Resour. Rural Dev. 2017, 9, 56-66. [CrossRef]

2. IRC. Community Water Supply Management: History of a Concept; IRC: Delft, The Netherlands, 2003.

3. Garn, H.A. Lessons from Large-Scale Rural Water and Sanitation Projects: Transition and Innovation. In Proceedings of the UNDP-World Bank Water and Sanitation Program, Washington, DC, USA, 1 August 1997.

4. Sara, J.; Katz, T. Making Rural Water Supply Sustainable: Report on the Impact of Project Rules. In Proceedings of the UNDP—World Bank Water and Sanitation Program, Washington, DC, USA, 1 August 1997; Available online: https://www.wsp.org/sites/wsp.org/files/publications/global_ruralreport.pdf (accessed on 13 June 2018).

5. Nicol, A.; Mehta, L.; Allouche, J. Introduction: "Some for all rather than more for some"? Contested pathways and politics since the 1990 New Delhi Statement. IDS Bull. 2012, 43, 1-9. [CrossRef]

6. Schouten, T.; Moriarty, P. Community Water, Community Management: From System to Service in Rural Areas; ITDG Publishing: London, UK, 2003.

7. Harvey, P.A.; Reed, R.A. Community-managed water supplies in Africa: Sustainable or dispensable? Commun. Dev. J. 2006, 42, 365-378. [CrossRef]

8. RWSN. Afridev Handpump Specification. Available online: http://www.rural-water-supply. net/_ressources/documents/default/AFRIDEV_Handpump-Specification_Rev-5-2007.pdf (accessed on 15 June 2018).

9. Chowns, E. Is community management an efficient and effective model of public service delivery? Lessons from the rural water supply sector in Malawi. Public Adm. Dev. 2015, 35, 263-276. [CrossRef]

10. Whittington, D.; Davis, J.; Prokopy, L.; Komives, K.; Thorsten, R.; Lukacs, H.; Bakalian, A.; Wakeman, W. How well is the demand-driven, community management model for rural water supply systems doing? Evidence from Bolivia, Peru and Ghana. Water Policy 2009, 11, 696-718. [CrossRef]

11. Harvey, P.A.; Reed, R.A. Rural Water Supply in Africa: Building Blocks for Handpump Sustainability; WEDC Loughborough University: Loughborough, UK, 2004.

12. Baumann, E.; Ball, P.; Beyene, A. Rationalization of Drilling Operations in Tanzania: Review of the Borehole Drilling Sector in Tanzania. 2005. Available online: https://www.sswm.info/sites/default/files/reference_ attachments/BAUMANN\%20et\%20al\%202005\%20Rationalization\%20of\%20Drilling\%20Operations\% 20in\%20Tanzania.pdf (accessed on 28 July 2018). 
13. Sutton, S. The Sub-Saharan Potential for Household Level Water Supply Improvement, Maximizing the Benefits from Water and Environmental Sanitation. In Proceedings of the 31st WEDC Conference, Kampala, Uganda, 31 October-4 November 2005; Available online: https:/ /www.ircwash.org/sites/default/ files/084201502triple-s_bn03defweb_1.pdf (accessed on 11 July 2018).

14. Hazelton, D. The Development of Community Water Supply Systems Using Deep and Shallow Well Handpumps; WRC Report No. TT132/00; Water Research Centre: Pretoria, South Africa, 2000.

15. Tanzania, W. Management for Sustainability: Practical Lessons from Three Studies on the Management of Rural Water Supply Schemes. WaterAid Tanzania Dar es Salaam Tanzania 2009, 26, 1-26.

16. Macri, G.; Rickard, A.; Asaba, R.B.; Mugumya, F.; Fagan, G.H.; Munck, R.; Asingwire, N.; Kabonesa, C.; Linnane, S. A Socio-Spatial Survey of Water Issues in Makondo Parish, Uganda; Dublin City University: Dublin, Ireland, 2013.

17. Tincani, L.; Ross, I.; Zaman, R.; Burr, P.; Mujica, A.; Evans, B. Regional Assessment of the Operational Sustainability of Water and Sanitation Services in Sub-Saharan Africa. Available online: www.vfm-wash.org (accessed on 18 July 2018).

18. Liddle, E.S.; Fenner, R. Water point failure in sub-Saharan Africa: The value of a systems thinking approach. Waterlines 2017, 36, 141-166. [CrossRef]

19. Carter, R.; Ross, I. Beyond "functionality" of handpump-supplied rural water services in developing countries. Waterlines 2015, 35, 94-110. [CrossRef]

20. Foster, T. Predictors of sustainability for community-managed handpumps in Sub-Saharan Africa: Evidence from Liberia, Sierra Leone, and Uganda. Environ. Sci. Technol. 2013, 47, 12037-12046. [CrossRef] [PubMed]

21. United Nations. The Millennium Development Goals Report: Time for Global Action for People and Planet. Available online: http:/ / www.un.org/millenniumgoals/2015_MDG_Report/pdf/MDG\%202015\%20rev\% 20(July\%201).pdf (accessed on 18 May 2018).

22. Chowns, E. The Political Economy of Community Management: A Study of Factors Influencing Sustainability in Malawi's Rural Water Supply Sector. Ph.D. Thesis, University of Birmingham, Birmingham, UK, January 2014.

23. Glotzbach, R.; Barakzai, S.; Adisu, J.; Tiwari, C. Functionality: The Challenge to Sustain Rural Water Supply Services; SNV Practice Brief: The Hague, The Netherlands, 2013; Volume 5, pp. 1-8.

24. Bey, V.; Magara, P.; Abisa, J. Assessment of the Performance of the Service Delivery Model for Point Water Sources in Uganda; Final Research Report, WASH; IRC: Hague, The Netherlands, 2014.

25. Welle, K.; Williams, J. Monitoring and Addressing Governance Factors Affecting Rural Water Supply Sustainability. Available online: http:/ / pubs.iied.org/pdfs/G03920.pdf) (accessed on 22 May 2018).

26. Carter, R.; Harvey, E.; Casey, V. User Financing of Rural Handpump Water Services. In Proceedings of the IRC Symposium 2010: Pumps, Pipes and Promises, Hague, The Netherlands, 16-18 November 2010.

27. Matamula, S. Access to sanitation and safe water: Community based management for sustainable water supply in Malawi. In Proceedings of the 33rd WEDC International Conference on Access to Sanitation and Safe Water: Global Partnerships and Local Actions, Accra, Ghana, 7-11 April 2008.

28. Bonsor, H.C.; Oates, N.; Chilton, P.J.; Carter, R.C.; Casey, V.; Macdonald, A.M.; Alowo, R.; Wilson, P.; Tumutungire, M.; Bennie, M. A Hidden Crisis: Strengthening the Evidence Base on the Sustainability of Rural Groundwater Supplies: Results from a Pilot Study in Uganda; UPGro Catalyst Grant Report NE/L001969/1; BGS: Edinburgh, UK, June 2015.

29. Mugumya, F. Enabling Community-Based Water Management Systems: Governance and Sustainability of Rural Point-Water Facilities in Uganda. Ph.D. Thesis, Dublin City University, Dublin, Ireland, December 2013.

30. Asingwire, N. Shifting Paradigms in Social Policy Reform: A Cased of Demand versus Supply-Driven Approaches to Rural Safe Water Supply in Uganda. Ph.D. Thesis, Makerere University, Kampala, Uganda, November 2008.

31. Ministry of Water and Environment (MWE). Assessment of the Effectiveness of Community-Based Maintenance System for Rural Water Supply Facilities; Directorate of Water Development, Ministry of Water and Environment: Kampala, Uganda, 2011.

32. Ministry of Water and Environment (MWE). Water and Environment Sector Performance Report 2017. Available online: http:/ / envalert.org/wp-content/uploads/2017/09/2017-09-14_SPR-2017.pdf (accessed on 16 July 2018). 
33. Mengistu, B. Empowering Women and Girls: How Water, Sanitation and Hygiene Deliver Gender Equality; WaterAid Eastern Africa Region: Addis Ababa, Ethiopia, 2012.

34. Lammerink, M.; Bolt, E. Supporting Community Management: A Manual for Training in Community Management in the Water and Sanitation Sector; IRC: Delft, The Netherlands, 2002.

35. Wehn de Montalvo, U.W.; Alaerts, G. Leadership in knowledge and capacity development in the water sector: A status review. Water Policy 2013, 15, 1-14. [CrossRef]

36. Mvulirwenande, S.; Wehn, U.; Alaerts, G. Evaluating knowledge and capacity development in the water sector: Challenges and progress. Water Int. 2017, 42, 372-384. [CrossRef]

37. World Bank. Irrigation and OEM and System Performance in Southeast Asia: An OED Impact Study; Operations Evaluation Department Report 15824; World Bank: Washington, DC, USA, 1996.

38. Alaerts, G.J.; Hartvelt, F.J.A.; Patorni, F.M. Water Sector Capacity Building: Concepts and Instruments; AA Balkema: Rotterdam, The Netherlands, 1999.

39. Alaerts, G.J.; Kaspersma, J.M. Progress and Hallenges in Knowledge and Capacity Development. In Capacity Development for Improved Water Management; Taylor and Francis: London, UK, 2009.

40. Amico, K.L.; Wieland, M.L.; Weis, J.A.; Sullivan, S.M.; Nigon, J.A.; Sia, I.G. Capacity Building through Focus Group Training in Community based Participatory Research. Educ. Health 2014, 24, 638.

41. Craig, G. Community capacity-building: Something old, something new ... ? Crit. Soc. Policy 2007, 27, 335-359. [CrossRef]

42. Lusthaus, C.; Adrien, M.H.; Anderson, G.; Carden, F.; Montalvan, G.P. Organizational Assessment. A Framework for Improving Performance; IDRC: Ottawa, ON, Canada, 2002.

43. Morgan, P. The Concept of Capacity; European Centre for Development Policy Management (ECDPM): Maastricht, The Netherlands, 2006.

44. GTZ. Capacity Development in the Water Sector: How GTZ Supports Sustainable Water Management and Sanitation. Available online: https://www.protos.ngo/sites/default/files/library_assets/W_IWB_E85_ capacity_development.pdf (accessed on 4 August 2018).

45. Mvulirwenande, S.; Alaerts, G.; Wehn de Montalvo, U.W. From knowledge and capacity development to performance improvement in water supply: The importance of competence integration and use. Water Policy 2013, 15, 267-281. [CrossRef]

46. Zinke, J. Monitoring and Evaluation of Capacity and Capacity Development; European Centre for Development Policy Management: Maastricht, The Netherlands, 2006.

47. Alaerts, G.J.; Blair, T.L.; Hartvelt, F.J.A. A Strategy for Water Sector Capacity Building. In Proceedings of the UNDP Symposium, Delft, The Netherlands, 3-5 June 1991.

48. United Nations Development Programme (UNDP). Measuring Capacity. Available online: http:/ / www.undp.org/content/undp/en/home/librarypage/capacity-building/undp-paper-onmeasuring-capacity.html (accessed on 24 April 2018).

49. Organisation for Economic Co-operation and Development (OECD). The Challenges of Capacity Development: Working towards Good Practice; OECD: Paris, France, 2006.

50. Lusthaus, C.; Gary, A.; Murphy, E. Institutional Assessment: A Framework for Strengthening Organizational Capacity; IDRC: Ottawa, ON, Canada, 1995.

51. Sub County Development Programme Implementation of the Community Information System (CIS). Lwengo District Socio Economic Report Volume II, Kampala. Available online: http: / /www.ubos.org/onlinefiles/uploads/ubos/2009_HLG_\%20Abstract_printed/CIS+UPLOADS / CIS\%20Socio-economic\%20Reports/Lwengo.pdf (accessed on 26 May 2018).

52. The National Population and Housing Census 2014: Area Specific Profile Series. Available online: https: / / www.ubos.org/onlinefiles/uploads/ubos/2014CensusProfiles/ABIM.pdf (accessed on 3 May 2018).

53. Ministry of Water and Environment. Directorate of Water Resources Management. Available online: http:/ / www.mwe.go.ug/library / directorate-water-resource-management (accessed on 27 May 2018).

54. National Environmental Management Authority (NEMA). State of the Environment Report for Uganda 2010; National Environmental Management Authority (NEMA): Kampala, Uganda, 2010.

55. Adam, Y.O.; Pretzsch, J.; Darr, D. Land use conflicts in Central Sudan: Perceptions and local coping mechanisms. Land Use Policy 2015, 42, 1-6. [CrossRef]

56. Fagan, G.H.; Linnane, S.; McGuigan, K.; Rugumayo, A.I. Water is Life: Progress to Secure Safe Water Provision in Rural Uganda; Practical Action Publishing: Rugby, UK, 2015. 
57. Breeveld, R.; Hermans, L.; Veenstra, S. Water operator partnerships and institutional capacity development for urban water supply. Water Policy 2013, 15, 165-182. [CrossRef]

58. Kaplan, A. Capacity building: Shifting the paradigms of practice. Dev. Pract. 2000, 10, 517-526. [CrossRef]

59. EuropeAID. Toolkit for Capacity Development. Final Draft; Tools and Methods Series No. 6; European Commission: Brussels, Belgium, 2009.

60. Asaba, R.B. Gender and representation in local water governance in rural Uganda. Int. J. Agric. Resour. Gov. Ecol. 2015, 11, 247-259. [CrossRef]

61. Pascual Sanz, M.; Veenstra, S.; Wehn de Montalvo, U. What counts as 'results' in capacity development partnerships between water operators? A multi-path approach toward accountability, Adaptation and learning. Water Policy 2013, 15, 242-266. [CrossRef]

62. Anderson, D. Organization Development. The Process of Leading Organizational Change; SAGE Publication Inc.: Thousand Oaks, CA, USA, 2010.

63. Bruns, B.R. Aiding Adaptive Co-management in Irrigation. In Proceedings of the 12th Biennial Global Conference of the International Association for the Study of the Commons, Cheltenham, UK, 14-18 July 2008.

(C) 2018 by the authors. Licensee MDPI, Basel, Switzerland. This article is an open access article distributed under the terms and conditions of the Creative Commons Attribution (CC BY) license (http://creativecommons.org/licenses/by/4.0/). 